\title{
Effects of management regimes on structure, composition and diversity of seasonally inundated herbaceous communities in the Mkomazi National Park, Tanzania
}

\author{
Oliver Castor Nyakunga ${ }^{1,2}$ (D) | Silvia Del Vecchio ${ }^{1}$ | Gabriella Buffa ${ }^{1}$
}

${ }^{1}$ Department of Environmental Sciences, Informatics and Statistics, University Ca'Foscari of Venice, Venice, Italy

${ }^{2}$ College of African Wildlife Management, Mweka (CAWM), Moshi, Tanzania

\section{Correspondence}

Oliver Castor Nyakunga, Department of Environmental Sciences, Informatics and Statistics, University Ca'Foscari of Venice, Venice, Italy.

Email: onyakunga@mwekawildlife.ac.tz

Funding information

The Italian Ministry of Education, University and Research (MIUR)

\begin{abstract}
The effects of management regimes on structural composition and diversity of seasonally inundated herbaceous communities were investigated in the Mkomazi National Park, Tanzania. Three sites were selected based on management regimes, that is "fire-grazing" (FG), "fire-no grazing" (FNG) and "no fire-no grazing" (NFNG), and sampled in the 2015 wet season. The studied vegetation parameters resulted significantly different across the sites, with the exceptions of species abundance between NFNG versus FG and NFNG versus FNG sites and species evenness, which remained constant among sites. A significantly higher species richness, Shannon diversity Index, standing biomass and percentage vegetation cover was detected at FNG site, than in the other sites. No significant differences arose when comparing FG and NFNG sites. Although the responses we found may in part be caused by confounding underlying variables such as variation in soil type, soil moisture or elevation, the patterns found may contribute to a more general understanding of the effects of management regimes in seasonally inundated savannah, as well as to sound approaches in environmental conservation and management. However, further research is needed to support our findings, replicating the study in other areas under the same or similar management conditions and in a wider array of ecosystems.
\end{abstract}

Résumé

Nous avons étudié les effets de différents régimes de gestion sur la composition structurelle et la diversité de communautés herbacées, inondées selon les saisons, dans le Parc National de Mkomazi, en Tanzanie. Nous avons sélectionné trois sites en fonction du régime de gestion, à savoir feux-pâturage (FG), feux-pas de pâturage (FNG) et pas de feux-pas de pâturage (NFNG) et nous y avons prélevé des échantillons pendant la saison des pluies de 2015. Les paramètres de la végétation étudiés étaient significativement différents dans les trois sites, à l'exception de l'abondance des espèces entre NFNG et FG, et entre NFNG et FNG, et de la régularité des espèces qui restait constante dans les sites. Nous avons détecté une richesse en espèces, un Indice de diversité de Shannon, une biomasse aérienne et un pourcentage de la couverture végétale significativement plus grands sur le site FNG que sur les autres. Aucune différence marquée n'est apparue lors de la comparaison des sites FG et NFNG. Même si les réponses que nous avons obtenues peuvent être dues en 
partie à des variables confusionnelles sous-jacentes telles que la variation du type de sol, de son humidité ou de son élévation, les schémas découverts pourraient contribuer à une meilleure compréhension générale des effets des régimes de gestion sur une savane inondée de façon saisonnière, ainsi qu'à des approches réfléchies de la conservation et de la gestion environnementales. II faudra cependant d'autres recherches pour étayer nos résultats, en répliquant cette étude dans d'autres régions dans des conditions de gestion identiques ou comparables et dans une plus grande variété d'écosystèmes.

\section{KEYWORDS}

disturbance, diversity, fire, grasslands, grazing, vegetation structure

\section{1 | INTRODUCTION}

Savannah constitutes one of the largest biomes of the world, with approximately $20 \%$ of the terrestrial land surface (Buitenwerf, Swemmer, \& Peel, 2011; Cech, Venterink, \& Edwards, 2010; Jeltsch, Weber, \& Grimm, 2000; Pratt \& Gwynne, 1997), comprising a dynamic mosaic of grasses and trees (Beerling \& Osborne, 2006; Van Langevelde et al., 2003). The herbaceous component of tropical savannah is dominated by a diverse array of $\mathrm{C}_{4}$ grasses (Smith et al., 2012), contributing significantly to herbaceous productivity and in turn providing forage for both wildlife and domestic stock. The balance between herbaceous and woody vegetation is regulated by complex interactions between climate, soil characteristics, and disturbance regimes, which include fire, grazing and browsing (Fuhlendorf, Briske, \& Smeins, 2001; Scholes \& Walker, 1993).

In mesic and humid African savannahs, fire is a naturally occurring phenomenon and plays a major role in determining the diversity, composition and structure of these ecosystems (Cech et al., 2010; Govender, Trollope, \& Van Wilgen, 2006; Walker, 1987). Anthropogenic fires in Africa are an ancient form of environmental disturbance, which probably has shaped the savannah vegetation more than any other human disturbance (Gandiwa, 2011; Smith et al., 2012). Grazing can be regarded as the second-most important disturbance on vegetation. Similar to fire, grazing exerts considerable changes on vegetation, in terms of species composition, structure, plant cover and biomass (Díaz et al., 2007; Kgosikoma, Mojeremane, \& Harvie, 2013; Savadogo, Tiveau, Sawadogo, \& Tigabu, 2008; Weiher et al., 1999).

In Tanzanian protected areas, fire is seen as a habitat management practice. Over decades, it has been considered as a prime management tool in solving ecological problems related to vegetation (Hassan, Rusch, Hytteborn, Skarpe, \& Kikula, 2007; Rau, Chambers, Blank, \& Johnson, 2008; Van De Vijver, 1999). Prescribed annual fire is normally used to reduce the amount of fuel to minimize the effects of unintended fires, promote regeneration of young sprouts for grazers and control bush encroachment, among other uses. Grazing in Tanzanian savannahs is also a naturally occurring phenomenon influencing savannah ecosystem functioning. Indeed, wildlife managers have little control over wild animal populations and their movements, and several ungulates are left to roam freely and graze.

These two disturbance factors are distributed differently in terms of duration and severity (Keeley, Brennan, \& Pfaff, 2008) and can act independently or additively (Belsky, 1992; Savadogo et al., 2008). The co-occurrence of these disturbances has a synergistic effect on plant communities, both in time and space (Savadogo et al., 2008). This, in turn, influences the composition and distribution of wildlife populations. Fire alters foraging patterns thereby influencing grazing, and grazers reduce fuel loads and alter fire spread in the landscape thus affecting fire (Archibald, Bond, Stock, \& Fairbanks, 2005).

Although prescribed fire is a prominent feature of most savannah ecosystems, in many protected areas, fire has been used as a common practice without explicitly evaluating its influence on soil, floristic composition and structure, biomass productivity and the possible synergistic effects of grazing. As management actions on vegetation induce responses and changes in the entire ecosystem, proper understanding of interactive effects of fire and grazing on savannah ecosystem dynamics is mandatory to maintain species diversity and productivity.

In the light of this, our primary objective was to analyze the effects of management regimes (i.e. "fire-grazing," "fire-no grazing" and "no fire-no grazing") on soil parameters, species diversity, composition and primary productivity of seasonally inundated grasslands in Mkomazi National Park, in north-eastern Tanzania.

\section{2 | MATERIALS AND METHODS}

\subsection{Study area}

The study was conducted in Mkomazi National Park $\left(3,276 \mathrm{~km}^{2}\right)$, in north-eastern Tanzania $\left(03^{\circ} 47^{\prime} \mathrm{S}-37^{\circ} 45^{\prime} \mathrm{E}\right.$ and $\left.04^{\circ} 33^{\prime} \mathrm{S}-38^{\circ} 45^{\prime} \mathrm{E}\right)$, with an elevation ranging from $230 \mathrm{~m}$ to $1,630 \mathrm{~m}$ a.s.l. (Coe, Mcwilliam, Stone, \& Packer, 1999). Mkomazi acquired its National Park status (i.e. allowing for nonconsumptive uses only) in 2005 from a game reserve since 1951 (i.e. permitting both consumptive and nonconsumptive uses) following increased degradation of biodiversity due to poaching and overgrazing by cattle. 
The climate is semi-arid with bimodally distributed and unpredictable rainfall, marked by short rains from October to December and main rains from March to May (Coe et al., 1999). Rainfall increases with altitude and accounts for an average annual precipitation of 570-890 mm (lowlands) and 911-1,910 mm (highlands) (Kelvin, 2013).

Phyto-geographically, the study sites are situated in the regional Centers of Endemism of Somali-Maasai and Afromontane and the Zanzibar Inhambane Regional mosaic dominated by grasses and trees of the families Poaceae, Euphorbiaceae, Acanthaceae, Asteraceae, Rubiaceae, Lamiaceae, Cyperaceae and Mimosaceae (Coe et al., 1999). However, data on vegetation date back to 1983 (Manguburi, 1983) and random observations suggest a rapid replacement of grassland by bush grassland (pers. field observations).

Key grazing species include Buffalo (Syncerus caffer), Elephant (Loxodonta africana), Zebra (Equus burchellii), Cokes' hartebeest (Alcelaphus buselaphus cokii) and Eland (Taurotragus oryx), that seasonally move between Mkomazi and Tsavo National Park in Kenya (Coe et al., 1999; Harris, 1972).

\section{2 | Study site selection}

Study areas were selected after a preliminary stratification of seasonally inundated grassland patches. In accordance with the sites were located in the lowlands, within a comparable elevation range (from 715 to $890 \mathrm{~m}$ a.s.I.), precipitation regimes $(570-890 \mathrm{~mm}$ ) and soil type (predominantly soft-textured atypical of black clay, derived from sites below and above large rocky inselbergs) (Anderson, 1967; Harris, 1972). To account for the effects of different management practices, we then identified three sites subjected to different management regimes: "fire-grazing" - FG (lat. $3^{\circ} 56^{\prime} \mathrm{W}$, long. $37^{\circ} 49^{\prime} \mathrm{N}$ ), "fire-no grazing" - FNG (lat. $4^{\circ} \mathrm{O}^{\prime} \mathrm{W}$, long. $37^{\circ} 49^{\prime} \mathrm{N}$ ), "no fire-no grazing"-NFNG (lat. $4^{\circ} 04^{\prime} \mathrm{W}$, long. $38^{\circ} 05^{\prime} \mathrm{N}$ ).

Sites subjected to fire (FG and FNG sites) were burnt each year, while NFNG site was not burnt since 2005. Burning was part of routine early-dry season burns undertaken by the Mkomazi Ecological Monitoring Programme Department. Site FG was grazed by an average of 3-15 resident individuals per day and occasionally in the wet season by small herds of Buffalo, Elephant or Eland of up to 80 individuals (pers. field observations). Sites FNG and NFNG were located in the proximity of frequently used roads and were avoided by animals (pers. field observations, a possible consequence of past hunting activities), while FG site was located in the proximity of a road used only for management purposes. Being subjected to low levels of disturbance as compared to FG and FNG sites, NFNG site was considered as a control site. Site extent varied between 300 and $400 \mathrm{~km}^{2}$.

\section{3 | Data collection}

Within each site, plot surveying was performed once between April and May 2015. Altogether 80 plots of $4 \mathrm{~m}^{2}$ were randomly established in each selected site. To avoid spatial autocorrelation, the minimum distance between plots was set at more than $250 \mathrm{~m}$ (Rezende, Eisenlohr, Vibrans, \& De Oliveira, 2015).

In each plot, species composition and abundance were recorded. Species abundance was determined by counting individual shoots. In the case of prostrate-stemmed grasses, tillers were counted. Taxonomic nomenclature follows Bogdan (1958) and Blundell (1987). The visual total percentage vegetation cover per plot was also estimated (Sutherland, 2006). Afterwards, in each plot, aboveground biomass was clipped from subquadrats $\left(0.5 \times 0.5 \mathrm{~m}\right.$; one for each $4 \mathrm{~m}^{2}$ plot). Clipped material was air-dried for 2 weeks in paper bags, later ovendried at $70^{\circ} \mathrm{C}$ (Mutanga et al., 2004) for $48 \mathrm{~h}$ and then weighed using a digital scale (Series $\mathrm{Cl}$ 201-China, with maximum $200 \mathrm{~g}, d=0.1 \mathrm{~g}$ ).

In each site, ten soil samples were randomly collected to a $20 \mathrm{~cm}$ depth from soil surface using a soil auger. Afterwards, samples were analyzed for $\mathrm{pH}$, total nitrogen $(\mathrm{N})$, carbon $(\mathrm{C})$, phosphorus $(\mathrm{P})$, potassium $(\mathrm{K})$, sodium $(\mathrm{Na})$ and calcium $(\mathrm{Ca})$ at the Agricultural Research Institute (ARI) Mlingano Laboratory in Tanga-Tanzania (Black, 1965; Bray \& Kurtz, 1945; Nelson \& Sommers, 1982).

For each site, we calculated species abundance, richness $(S)$, Shannon Diversity Index $\left(H^{\prime}\right)$ and Evenness Index $(J)$ (calculated as $H^{\prime} /$ In $S$, where $H^{\prime}$ is the Shannon diversity index and $S$ the number of species; Magurran, 2004), percentage vegetation cover, perennials abundance (\%) and standing biomass $\left(\mathrm{g} \mathrm{m}^{-2}\right)$, as the average of the plots ( $n=80$ per site). We similarly calculated the average of each soil parameter ( $n=10$ per site).

To categorize species based on their abundances, we theoretically defined four classes as most abundant (with a number of individuals $>1,000$ ), abundant (with individuals between 999 and 500), intermediate abundance (with individuals between 499 and 100) and low abundance (with individuals $<100$ ).

\subsection{Statistical analyses}

Floristic gradients were analyzed using Detrended Correspondence Analysis (DCA) from a matrix of 101 species $\times 240$ plots (Pc-ord 5.1 software; Mccune \& Mefford, 2011). The effects of management regime on species abundance, richness, evenness and diversity, percentage vegetation cover, percentage perennials abundance and biomass productivity were tested by PERMANOVA with 9,999 randomization, using the site as the grouping variable (factor with three categories: FG, FNG and NFNG). We similarly tested the differences in the soil parameters among the sites. The differences among the sites were separated by the post hoc Tukey HSD test. Statistical analysis was performed using the Past software (Hammer, Harper, \& Ryan, 2001). Species dominance was computed using Microsoft $^{\circledR}$ Excel for Windows ${ }^{\mathrm{T}}$.

\section{3 | RESULTS}

The three sites separated out well in the ordination space (Figure 1) with FG and FNG sites at the lower extreme of axis 1, and more similar to each other compared to NFNG site. 


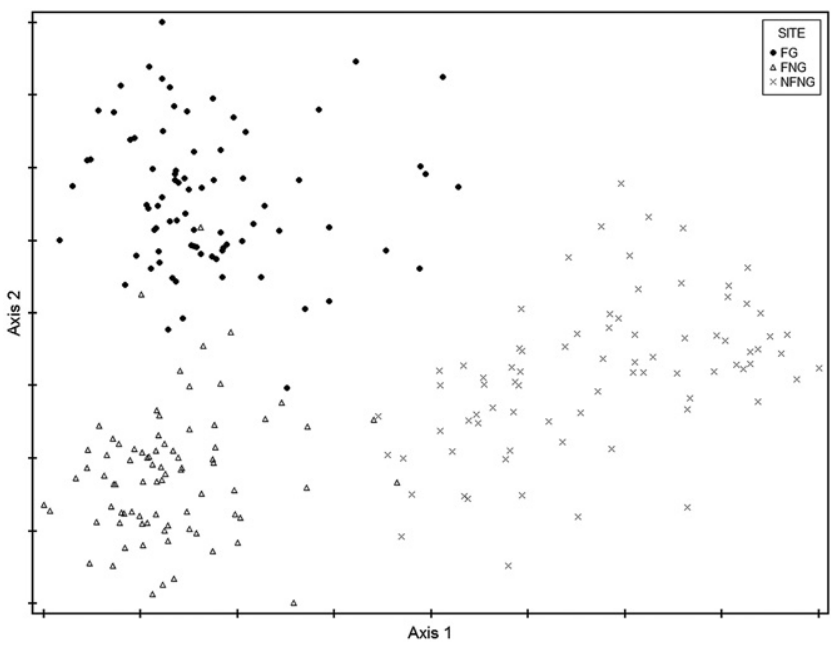

FIGURE 1 Diagram of detrended correspondence analysis (DCA) ordination of the 240 plots (101 species). Eigenvalues were 0.59 and 0.29 for DCA axis 1 and 2, respectively, and length of gradients was 3.6 and $2.8 S D$

A total of 101 plant species (Supporting information Appendix S1) representing 71 genera and 23 families was recorded. A total of 53, 62 and 62 species were identified, respectively, from NFNG, FG and FNG sites.

Species composition differed among sites, with only 21 species in common among the sites (Supporting information Appendix S1), mostly represented by species with intermediate or low abundance. Overall, the vegetation structure was similar across the sites with few dominant or subdominant species (i.e. with more than 1,000 and 500 individuals, respectively, in a $4 \mathrm{~m}^{2}$ plot) and many species with intermediate or low abundance. However, dominant or subdominant species were perennial grasses such as Pennisetum ciliare and Echinochloa haploclada in NFNG, and Digitaria milanjiana, Themeda triandra and Andropogon distachyos in FG site, while in FNG site the most abundant species was the annual forb Commelina petersii.

The PERMANOVA indicated a significant effect of the site on the analyzed plant community parameters (PERMANOVA test; $F=27.75 ; p<0.001$ ). The Tukey test (Table 1) showed significant differences in all parameters, with the exceptions of species abundance and evenness which were not significantly different among sites. In particular, FNG site showed significantly higher species richness, species diversity, standing biomass and percentage vegetation cover per plot when compared to both FG and NFNG sites. No significant difference was found when comparing FG versus NFNG. Plots of NFNG site showed a significantly higher per cent of perennial abundance when compared to both FG and FNG sites.

Soil parameters $(\mathrm{pH}$, total nitrogen, carbon, phosphorus, potassium, sodium and calcium) turned out to be significantly different (PERMANOVA test; $F=5.05 ; p=0.004$ ). However, only NFNG site evidenced significant differences in pairwise comparison (Tukey HSD test; Table 2). No significant differences arose between FG versus FNG.

\section{DISCUSSION}

Seasonally inundated herbaceous communities subjected to different management regimes showed significant differences in both species composition and vegetation structure, particularly striking when comparing the control, less-disturbed site (NFNG) with sites subjected to disturbance (FG and FNG).

Frequent burning and grazing (FG site) select for plants with belowground organs (e.g. rhizomes) which guarantee the capacity to replace new shoots or regrowth after fire (e.g. D. milanjiana, A. distachyos, Ischaemum afrum, Setaria sphacelata and Bothriochloa insculpta) thus easily recovering from the effects of the two disturbances. At the same time, frequent fires promote tall fire-dependent bunchgrasses (Archibald et al., 2005) as evidenced by the abundance of $T$. triandra. Contrary to expectations, our results did not show a significant decrease in species richness in the grazed site compared with the control site (NFNG). Herbivores have been proved to affect vegetation structure and composition by mostly grazing on highquality plant species (Haarmeyer, Schmiedel, Dengler, \& Bösing, 2010; Huntly, 1991; Rutherford \& Powrie, 2013), thus favouring the dominance of a few species that tolerate grazing pressure (Collins, 1987). However, grazing can also contribute to allow different plant species to coexist by preferentially consuming competitively dominant plants (Collins, 1987; Davies \& Bodart, 2015). Indeed, several studies found that grazing may induce changes in vegetation structure without negatively affecting species richness (see e.g. Todd \& Hoffman, 2009). Furthermore, Rutherford and Powrie (2010) found positive effects of grazing on both Shannon diversity and evenness. In the Serengeti grassland communities, Belsky (1992) found that in grazed blocks, large herbivores prevented several species (e.g. Pennisetum mezianum) from growing large enough to outcompete other species, while the same species grew to their full ungrazed height and overtopped shorter species in protected blocks. At the same time, grazing can also favour colonization processes by enhancing propagule dispersal and increasing availability of light and soil nutrients (Han \& Mark, 1998; Noy-Meir, 1995). The high number of individuals of an annual broad-leafed species (Hermannia uhligii) confirms the contribution of grazers in seed dispersal, as most of its seedlings were seen to emerge from the decomposed dung of herbivores. At the same time, these results suggest that the assumed negative effect of grazing on plant species richness (e.g. Milton, Dean, Du Plessis, \& Siegfried, 1994; Mucina et al., 2006) cannot be generalized (Rutherford, Powrie, \& Husted, 2012).

In our case, the effect of grazing could be counterbalanced by the synchronous presence of fire. Fire alone (FNG site) tended to have a positive effect on species richness and diversity per plot. However, the increase was mostly due to annual species. According to Jensen, Michelsen, and Gashaw (2001), the establishment of herbaceous species in mesic savannahs, such as in this park, is related to fire intensity and severity. Early burning (i.e. a few months after the rains) tends to be of low intensity as vegetation still holds moisture from the wet season, thereby favouring the germination of several herbaceous species, enhancing the availability of nutrients, 
TAB LE 1 Tukey HSD results comparing the plot means $( \pm S E)$ for species abundance, vegetation cover (\%), perennial abundance (\%), species richness $(n)$, evenness $(E)$ and diversity $\left(H^{\prime}\right)$, and standing biomass $\left(\mathrm{g} \mathrm{m}^{-2}\right)$ of the three sites

\begin{tabular}{|c|c|c|c|c|c|c|}
\hline \multirow[b]{2}{*}{$\begin{array}{l}\text { Species composition parameters } \\
(n=240)\end{array}$} & \multirow[b]{2}{*}{ FG } & \multirow[b]{2}{*}{ FNG } & \multirow[b]{2}{*}{ NFNG } & \multicolumn{3}{|c|}{ Tukey HSD test } \\
\hline & & & & $\begin{array}{l}\text { FG versus } \\
\text { FNG }\end{array}$ & $\begin{array}{l}\text { FG versus } \\
\text { NFNG }\end{array}$ & $\begin{array}{l}\text { FNG versus } \\
\text { NFNG }\end{array}$ \\
\hline Vegetation cover (\%) & $67.25 \pm 17.06$ & $83.3 \pm 8.93$ & $60.84 \pm 15.24$ & * & * & $* *$ \\
\hline Perennial abundance (\%) & $76.13 \pm 20.50$ & $60.25 \pm 26.60$ & $89.09 \pm 12.46$ & $*$ & $*$ & $*$ \\
\hline Shannon index $\left(H^{\prime}\right)$ & $1.32 \pm 0.41$ & $1.64 \pm 0.42$ & $1.28 \pm 0.37$ & * & ns & * \\
\hline Standing biomass $\left(\mathrm{g} \mathrm{m}^{-2}\right.$ ) & $442.08 \pm 99.62$ & $675.76 \pm 151.76$ & $363.43 \pm 62.61$ & $* * *$ & ns & $* * *$ \\
\hline
\end{tabular}

Note: NFNG: "no fire-no grazing" site; FG: fire-grazing" site; FNG: "fire-no grazing" site.

$* p<0.05, * * p<0.01, * * * p<0.01$.

TABLE 2 Tukey HSD results comparing the plot means $( \pm S E ; n=10)$ for soil parameters in the three study sites: NFNG = "no fire-no grazing" site; FG = "fire-grazing" site; FNG = "fire-no grazing" site

\begin{tabular}{|c|c|c|c|c|c|c|}
\hline \multirow[b]{2}{*}{ Soil characteristics } & \multirow[b]{2}{*}{ FG } & \multirow[b]{2}{*}{ FNG } & \multirow[b]{2}{*}{ NFNG } & \multicolumn{3}{|l|}{ Tukey HSD test } \\
\hline & & & & FG versus FNG & FG versus NFNG & FNG versus NFNG \\
\hline $\mathrm{pH}\left(\mathrm{H}_{2} \mathrm{O}\right)$ & $7.06 \pm 0.11$ & $7.17 \pm 0.13$ & $8.02 \pm 0.21$ & ns & $*$ & * \\
\hline Total N\% & $0.09 \pm 0.02$ & $0.10 \pm 0.14$ & $0.18 \pm 0.49$ & ns & $*$ & $*$ \\
\hline $\mathrm{P}(\mathrm{mg} / \mathrm{kg})$ & $5.91 \pm 1.70$ & $4.93 \pm 1.97$ & $3.27 \pm 0.25$ & ns & * & ns \\
\hline $\mathrm{K}(\mathrm{Cmol} / \mathrm{kg})$ & $0.36 \pm 0.11$ & $0.55 \pm 0.17$ & $1.97 \pm 0.56$ & ns & * & * \\
\hline $\mathrm{Na}(\mathrm{Cmol} / \mathrm{kg})$ & $0.72 \pm 0.14$ & $0.76 \pm 0.36$ & $0.45 \pm 0.34$ & ns & ns & ns \\
\hline
\end{tabular}

Note: ${ }^{*} p<0.05$, ns $p>0.1$.

space and light, and favouring tillering of tussocks (Garnier \& Dajoz, 2001; Williams, Cook, Gill, \& Moore, 1999). Indeed, prescribed burning had the strongest effects on plant community richness and diversity, vegetation cover and aboveground plant biomass, compared to grazing. The high abundance of annuals could also be explained by other factors such as spatially differing soil moisture patterns or soil water storage capacity (Gillson \& Hoffman, 2007). This suggestion is supported by the higher soil moisture found in FNG site (pers. field observations) which remained humid when FG and NFNG sites had already dried out. Such availability of moisture might have facilitated the colonization of annual species on open spaces created by fire. High biomass values may also be linked to the significant differences in soil nutrient availability, with soil of both FG and FNG sites having a significantly higher phosphorus content than in NFNG site. Indeed, studies in mesic grasslands suggest that inorganic phosphorous and other minerals are often higher on burned than unburned plots (Travers, 1999; Valone, 2003).

The lower level of disturbance in NFNG site could explain the significantly higher abundance of perennials, as annual species often dominate when disturbance is frequent as already stated for several ecosystems (Buffa \& Villani, 2012; Del Vecchio, Pizzo, \& Buffa, 2015; Díaz et al., 2007; Valone \& Kelt, 1999). However, other ecological factors can promote the dominance of a species (Fantinato, Del Vecchio, Giovanetti, Acosta, \& Buffa, 2018; Fantinato et al., 2016; Pierce et al., 2017). Thus, the overabundance of $P$. ciliare in NFNG site is most likely associated with its high level of tolerance to drought and the ability to respond more rapidly to rain than other species (Jackson, 2005). Vice versa, the abundance of Eustachys paspaloides in NFGN site may be attributed to its opportunistic behaviour of growing in depressed localities (geographically restricted), which often collect water and nutrients from adjacent surroundings (pers. field observation), which is possibly an opportunistic exploitation of temporarily favourable resources (Grime, 1977). Although not abundant, these depressed localities were observed only in NFNG site.

The results of this study indicate that FG (i.e. high disturbance level) and NFNG (no disturbance) had the lowest richness and diversity when compared with FNG site. These results possibly suggest that fire and grazing interactively, although not necessarily simultaneously (i.e. not at the same time of the year), impact species richness and diversity by directly consuming or damaging biomass. By killing plants in standing vegetation or destroying germinating seeds, they affect plant growth and regeneration and in turn the recruitment of young seedlings. This process affects both the number of 
species, selecting those species able to withstand or recover after disturbance, and species abundance, allowing some species to become dominant as exemplified by T. triandra in FG site. On the other hand, NFNG site had the lowest cumulative number of species and the lowest number of species per plot, as well as the lowest aboveground biomass. This suggests that the absence of disturbance might lead to the loss of diversity and productivity, and to the dominance of a few species such as $P$. ciliare. The effects of this species on the diversity and cover of other species are well documented in different grasslands in many parts of the world (Hussain, Ahmad, \& Ilahi, 2010; Hussain, Naqvi, \& Ilahi, 1982; Jackson, 2005; Marshall, Lewis, \& Ostendorf, 2012). Nonetheless, several other ecological factors including its high level of tolerance to drought and ability to respond more rapidly to rain than other species (Jackson, 2005) may have contributed to promote its dominance. At an intermediate level of disturbance (i.e. FNG site), fire opens up space for colonization and reduces the competitive superiority of dominant species (Collins, 1987), increases plant vigour and favour the growth of annual herbs, thereby increasing the herb layer diversity and cover. This result relates to the intermediate disturbance hypothesis (Grime, 1973), which assumes higher plant richness and diversity and higher productivity at intermediate levels of disturbance.

Our results differ from previous studies in other savannah systems that have documented significant positive effects of fire and large grazers either collectively or independently on plant species richness and diversity (Collins, 1987; Hartnett, Hickman, \& Walter, 1996; Heady, 1966; Valone \& Kelt, 1999; Zhang, 1998). Collins (1987) reported higher species richness on plots that were both burned and grazed at Konza prairie. Noy-Meir (1995) found higher species richness and diversity of grazed sites with a consistent increase in species richness after a fire on fire-ungrazed sites of the Mediterranean grasslands. However, analysis of the literature showed several discrepancies. Such contrasting results may derive from differential responses of individual plant species to fire and grazing in different geographical regions and plant communities (Haarmeyer et al., 2010; Rutherford \& Powrie, 2013). Species responses may also depend on disturbance intensity and frequency, which in turn are influenced by a wide range of local biotic and abiotic variables (e.g. animal species and density, grazing intensity, climatic condition, soil characteristics, vegetation structure or individual species attributes) (Del Vecchio, Slaviero, Fantinato, \& Buffa, 2016; Mataix-Solera, Cerdà, Arcenegui, Jordán, \& Zavala, 2011; Pyne, Patricia, \& Richard, 1996). More widely, the responses we found may in part be caused by confounding underlying variables such as local variation in soil moisture, or elevation. Although we structured the sampling design spreading plots to cover a wide surface in order to limit as much as possible pseudo-replication bias, logistical constraints prevented us from selecting more sites to eliminate unit effects. Moreover, although the three sites were selected so as to remove or minimize across-sites environmental heterogeneity in terms of climate and soil characteristics, we cannot exclude finescale inherent differences among the sites (e.g. depressed localities in NFNG site), which could have affected our results. These possible criticalities suggest that further research is needed to support our findings, replicating the study in other areas under the same management conditions and in a wider array of ecosystems. The comparison of results from other studies will overcome these limits and improve our knowledge.

\section{5 | CONCLUSION}

The patterns found in this study may contribute to a more general understanding of the effects of management regimes in seasonally inundated savannah, as well as to sound approaches in environmental conservation and management. Management is a crucial component of the establishment of native vegetation and the development of a diverse and healthy plant community. From a management perspective, the application of early fire should continue to be used as a management tool with attention to the timing of burning, weather conditions and other possible factors that may increase fire intensity. In particular, early fire is an important management tool from the perspective of biodiversity conservation, meeting qualitative (species richness and diversity) as well as quantitative (biomass) management criteria in Mkomazi National Park. Grazing could be allowed at a moderate level, as wildlife-based tourism is the main source of income for the local people.

\section{ACKNOWLEDGEMENTS}

Authors want to thank the Directors of Tanzania National Parks and Tanzania Wildlife Research Institute for permission to work in the Mkomazi National Park, Chief Park Warden of the same Park for support while in Mkomazi. Carlo, Veronica, Festo and Getruda for dedicated field assistance. This research was supported by the Italian Ministry of Education, University and Research (MIUR).

\section{ORCID}

Oliver Castor Nyakunga iD http://orcid.org/0000-0002-6029-0076

\section{REFERENCES}

Anderson, G. D. (1967). A reconnaissance survey of the land use potential of Mkomazi Game Reserve and an appraisal of factors affecting present and potential land use and productivity in its environs'. Dar Es Salaam, Tanzania: Unpublished report to the Ministry of Agriculture and Cooperatives.

Archibald, S., Bond, W. J., Stock, W. D., \& Fairbanks, D. H. K. (2005). Shaping the landscape: Fire-grazing interactions in An African Savanna. Ecological Applications, 15, 96-109. https://doi.org/10. 1890/03-5210

Beerling, D. K. J., \& Osborne, C. P. (2006). The origin of the savanna biome. Global Change Biology, 12, 2023-2031. https://doi.org/10. 1111/j.1365-2486.2006.01239.x

Belsky, J. A. (1992). Effects of grazing, competition, disturbance and fire on species composition and diversity in grassland communities. Journal of Vegetation Science, 3, 187-200. https://doi.org/10.2307/ 3235679 
Black, C. A. (1965). Methods of soil analysis. Part 2: Chemical and microbiological properties. Agronomy Series 9. Madison, WI: ASA.

Blundell, M. (1987). Wild flower of East Africa. Hong Kong, China: Harper Collins.

Bogdan, A. V. (1958). A revised list of Kenya grasses: With keys for identification. Pretoria, South Africa: Government Printer.

Bray, R. H., \& Kurtz, L. T. (1945). Determination of total organic and available phosphorus in soils. Soil Science, 59, 39-46. https://doi.org/ 10.1097/00010694-194501000-00006

Buffa, G., \& Villani, M. (2012). Are the ancient forests of the Eastern Po Plain large enough for a long term conservation of herbaceous nemoral species? Plant Biosystem, 146, 970-984. https://doi.org/10. 1080/11263504.2012.704887

Buitenwerf, R., Swemmer, A. M., \& Peel, J. S. M. (2011). Long-term dynamics of herbaceous vegetation structure and composition in two African savanna reserves. Journal of Applied Ecology, 48, 238-246. https://doi.org/10.1111/j.1365-2664.2010.01895.x

Cech, P. G., Venterink, H. O., \& Edwards, P. J. (2010). N and P cycling in Tanzanian humid savanna: Influence of herbivores, fire, and N2-fixation. Ecosystems, 13, 1079-1096. https://doi.org/10.1007/s10021010-9375-9

Coe, M. J., Mcwilliam, N. C., Stone, G. N., \& Packer, M. J., Eds. (1999). Mkomazi: The ecology, biodiversity and conservation of Tanzanian Savanna. London, UK: Royal Geographical Society (with the Institute of British Geographers)

Collins, S. L. (1987). Interaction of disturbances in tallgrass prairies: A field experiment. Ecology, 68, 1243-1250. https://doi.org/10.2307/ 1939208

Davies, G. M., \& Bodart, J. (2015). Changes in vegetation composition and diversity following livestock removal along an upland elevational gradient. iForest, 8, 582-589. https://doi.org/10.3832/if or1557-008

Del Vecchio, S., Pizzo, L., \& Buffa, G. (2015). The response of plant community diversity to alien invasion: Evidence from a sand dune time series. Biodiversity and Conservation, 24, 371-392. https://doi.org/10. 1007/s10531-014-0814-3

Del Vecchio, S., Slaviero, A., Fantinato, E., \& Buffa, G. (2016). The use of plant community attributes to detect habitat quality in coastal environments. AoB Plants, 8: plw040; https://doi.org/10.1093/aob $\mathrm{pla} / \mathrm{plw0} 40$

Díaz, S., Lavorel, S., Mcintyre, S. U. E., Falczuk, V., Casanoves, F., Milchunas, D. G., ... Landsberg, J. (2007). Plant trait responses to grazing-a global synthesis. Global Change Biology, 13, 313-341. https://doi.org/ 10.1111/j.1365-2486.2006.01288.x

Fantinato, E., Del Vecchio, S., Giovanetti, M., Acosta, A. T. R., \& Buffa, G. (2018). New insights into plants coexistence in species-rich communities: The pollination interaction perspective. Journal of Vegetation Science, 29, 6-14. https://doi.org/10.1111/jvs.12592

Fantinato, E., Del Vecchio, S., Slaviero, A. S., Conti, L., Acosta, A. T. R., \& Buffa, G. (2016). Does flowering synchrony contribute to the sustainment of dry grassland biodiversity? Flora, 222, 96-103. https://doi. org/10.1016/j.flora.2016.04.003

Fuhlendorf, S. D., Briske, D. D., \& Smeins, F. E. (2001). Herbaceous vegetation change in variable rangeland environments: The relative contribution of grazing and climatic variability. Applied Vegetation Science, 4, 177-188. https://doi.org/10.1111/j.1654-109X.2001.tb00486.x

Gandiwa, E. (2011). Effects of repeated burning on woody vegetation structure and composition in a semi-arid southern African savannah. International Journal of Environmental Sciences, 2, 458-471.

Garnier, L. K. M., \& Dajoz, I. (2001). The influence of fire on the demography of a dominant grass species of West African savannas, Hyparrhenia diplandra. Journal of Ecology, 89, 200-208. https://doi.org/10. 1046/j.1365-2745.2001.00532.x

Gillson, L., \& Hoffman, M. T. (2007). Rangeland ecology in a changing world. Science, 315, 53-54. https://doi.org/10.1126/science.1136577
Govender, N., Trollope, W. S. W., \& Van Wilgen, W. B. (2006). The effect of fire season, fire frequency, rainfall and management on fire intensity in savanna vegetation in South Africa. Journal of Applied Ecology, 43, 748-758. https://doi.org/10.1111/j.1365-2664.2006.01184.x

Grime, J. P. (1973). Competitive exclusion in herbaceous vegetation. Nature, 242, 344-347. https://doi.org/10.1038/242344a0

Grime, J. P. (1977). Evidence for the existence of three primary strategies in plants and its relevance to ecological and evolutionary theory. American Naturalist, 111, 1169-1194. https://doi.org/10.1086/ 283244

Haarmeyer, D. H., Schmiedel, U., Dengler, J., \& Bösing, B. M. (2010). How does grazing intensity affect different vegetation types in arid Succulent Karoo, South Africa? Implications for conservation management. Biological Conservation, 143, 588-596. https://doi.org/10. 1016/j.biocon.2009.11.008

Hammer, O., Harper, D. A. T., \& Ryan, P. D. (2001). PAST: Paleontological statistics software package for education and data analysis. Paleontologia Electrica, 4, 1-9.

Han, O., \& Mark, E. R. (1998). Effects of herbivore on grassland plant diversity. Trends in Ecology and Evolution, 13, 261-265.

Harris, L. D. (1972). An ecological description of a semi-arid East African ecosystem. Monographic Series. Series No. 11 Colorado State University. Fort Collins, CO: Range Science Department.

Hartnett, D. C., Hickman, K. R., \& Walter, L. E. F. (1996). Effects of bison grazing, fire, and topography on floristic diversity in tallgrass prairie. Journal of Range Management, 49, 413-420. https://doi.org/10.2307/ 4002922

Hassan, S. N., Rusch, G. M., Hytteborn, H., Skarpe, C., \& Kikula, I. (2007). Effects of fire on sward structure and grazing in western Serengeti, Tanzania. African Journal of Ecology, 46, 174-185.

Heady, H. F. (1966). Influence of grazing on the composition of Themeda triandra grassland, East Africa. Journal of Ecology, 54, 705-727. https://doi.org/10.2307/2257812

Huntly, N. (1991). Herbivores and the dynamic of communities and ecosystems. Annual Review of Ecology and Systematics, 22, 477-503. https://doi.org/10.1146/annurev.es.22.110191.002401

Hussain, F., Ahmad, B., \& Ilahi, I. (2010). Allelopathic effects of Cenchrus ciliaris L. and Bothriocloa pertusa (L.) A. Camus. Pakistan Journal of Botany, 42, 3587-3604.

Hussain, F., Naqvi, H. H., \& Ilahi, I. (1982). Interference exhibited by Cenchrus ciliaris L. and Bothriochloa pertusa (L.) A. Camus. Bulletin of the Torrey Botanical Club, 109, 513-523. https://doi.org/10.2307/ 2996492

Jackson, J. (2005). Is there a relationship between herbaceous species richness and buffel grass (Cenchrus ciliaris)? Austral Ecology, 30, 505 517. https://doi.org/10.1111/j.1442-9993.2005.01465.x

Jeltsch, F., Weber, G. E., \& Grimm, V. (2000). Ecological buffering mechanisms in savannas: A unifying theory of long-term tree-grass coexistence. Plant Ecology, 150, 161-171. https://doi.org/10.1023/A: 1026590806682

Jensen, M., Michelsen, A., \& Gashaw, M. (2001). Responses in plant, soil inorganic and microbial nutrient pools to experimental fire, ash and biomass addition in a woodland savanna. Oecologia, 128, 85-93. https://doi.org/10.1007/s004420000627

Keeley, J. E., Brennan, T., \& Pfaff, A. H. (2008). Fire severity and ecosystem responses following crown fires in California shrublands. Ecological Applications, 18, 1530-1546. https://doi.org/10.1890/07-0836.1

Kelvin, E. A. (2013). Early burn programme: Serengeti National Park. Internal MEMO, Unpublished Report. Arusha, Tanzania: Serengeti National Park (SNP)

Kgosikoma, O. E., Mojeremane, W., \& Harvie, B. A. (2013). Grazing management systems and their effects on savanna ecosystem dynamics: A review. Journal of Ecology and the Natural Environment, 5, 88-94. https://doi.org/10.5897/JENE

Magurran, A. (2004). Measuring biological diversity. Oxford, UK: Blackwell. 
Marshall, V. M., Lewis, M. M., \& Ostendorf, O. (2012). Buffel grass (Cenchrus ciliaris) as an invader and threat to biodiversity in arid environments: A review. Journal of Arid Environments, 78, 1-12. https://doi. org/10.1016/j.jaridenv.2011.11.005

Mataix-Solera, J., Cerdà, A., Arcenegui, V., Jordán, A., \& Zavala, L. M. (2011). Fire effects on soil aggregation: A review. Earth-Science Reviews, 109, 44-60. https://doi.org/10.1016/j.earscirev.2011.08.002

Mccune, B., \& Mefford, M. J. (2011). PC-ORD. Multivariate analysis of ecological data. Version 6. Gleneden Beach, OR: $\tilde{n}$.

Milton, S. J., Dean, W. R., Du Plessis, M. A., \& Siegfried, W. R. (1994). A conceptual model of arid rangeland degradation. BioScience, 44, 7076. https://doi.org/10.2307/1312204

Mucina, L., Jürgens, N., Le Roux, A., Rutherford, M. C., Schmiedel, U., Esler, K. J., ... Milton, S. J. (2006). Succulent Karoo biome. In L. Mucina, \& M. C. Rutherford (Eds.), The vegetation of South Africa, Lesotho and Swaziland (pp. 220-299). Pretoria, South Africa: South African National Biodiversity Institute.

Mutanga, O., Prins, H. H. T., Skidmore, A. K., Wieren, S., Huizing, H., Grant, R., ... Biggs, H. (2004). Explaining grass-nutrient patterns in a savanna rangeland of southern Africa. Journal of Biogeography, 31, 819-829. https://doi.org/10.1111/j.1365-2699.2004.01072.x

Nelson, D. W., \& Sommers, L. E. (1982). Total carbon, organic carbon and organic matter. In A. L. Page, R. H. Miller, \& D. R. Keeney (Eds.), Methods of soil analysis, part 2, agronomy series 9, 2nd ed. (pp. 539577). Madison, WI: ASA.

Noy-Meir, I. (1995). Interactive effects of fire and grazing on structure and diversity of Mediterranean grasslands. Journal of Vegetation Science, 6, 701-710. https://doi.org/10.2307/3236441

Pierce, S., Negreiros, D., Cerabolini, B. E. L., Kattge, J., Diaz, S., Kleyer, M., Shipley, B., Wright, S. J., Soudzilovskaia, N. A., ... Tampucci, D. (2017). A global method for calculating plant CSR ecological strategies applied across biomes world-wide. Functional Ecology, 31, 444 457. https://doi.org/10.1111/1365-2435.12722

Pratt, D. J., \& Gwynne, M. D. (1997). Rangeland management and ecology in East Africa. London, UK: Hodder and Stoughton.

Pyne, S. J., Patricia, L. A., \& Richard, D. L. (1996). Introduction to wildland fire, 2nd ed. New York, NY: John Wiley \& Sons.

Rau, B. M., Chambers, J. C., Blank, R. R., \& Johnson, D. W. (2008). Prescribed fire, soil, and plants: Burn effects and interactions in the central Great Basin. Rangeland Ecology and Management, 61, 169-181. https://doi.org/10.2111/07-037.1

Rezende, V. L., Eisenlohr, P. V., Vibrans, A. C., \& De Oliveira, A. T. (2015). Humidity, low temperature extremes, and space influence floristic variation across an insightful gradient in the subtropical Atlantic forest. Plant Ecology, 216, 759-774. https://doi.org/10.1007/ s11258-015-0465-9

Rutherford, M. C., \& Powrie, L. W. (2010). Severely degraded rangeland: Implications for plant diversity from a case study in Succulent Karoo, South Africa. Journal of Arid Environments, 74, 692-701. https://doi. org/10.1016/j.jaridenv.2009.10.013

Rutherford, M. C., \& Powrie, L. W. (2013). Impacts of heavy grazing on plant species richness: A comparison across rangeland biomes of South Africa. South African Journal of Botany, 87, 146-156. https://d oi.org/10.1016/j.sajb.2013.03.020

Rutherford, M. C., Powrie, L. W., \& Husted, L. B. (2012). Plant diversity consequences of a herbivore-driven biome switch from grassland to Nama-Karoo shrub steppe in South Africa. Applied Vegetation Science, 15, 14-25. https://doi.org/10.1111/j.1654-109X. 2011.01160.x

Savadogo, P., Tiveau, D., Sawadogo, L., \& Tigabu, M. (2008). Herbaceous species responses to long-term effects of prescribed fire, grazing and selective tree cutting in the savanna-woodlands of West Africa. Perspectives in Plant Ecology, Evolution and Systematics, 10, 179-185. https://doi.org/10.1016/j.ppees.2008.03.002
Scholes, R. J., \& Walker, B. H. (1993). An African savanna: Synthesis of the Nylsvley study. Cambridge, UK: University Press. https://doi.org/10. 1017/CBO9780511565472

Smith, M. D., Van Wilgen, B. W., Burns, C. E., Govender, N., Potgieter, A. L. F., Andelman, S., .. Trollope, W. S. W. (2012). Long-term effects of fire frequency and season on herbaceous vegetation in savannas of the Kruger National Park, South Africa. Journal of Plant Ecology, 20, 1-13.

Sutherland, W. J., Ed. (2006). Ecological census techniques: A handbook. Cambridge, UK: Cambridge University Press. https://doi.org/10. 1017/CBO9780511790508

Todd, S. W., \& Hoffman, M. T. (2009). A fence line in time demonstrates grazing-induced vegetation shifts and dynamics in the semiarid Succulent Karoo. Ecological Applications, 19, 1897-1908. https://doi.org/ 10.1890/08-0602.1

Travers, S. E. (1999). Pollen performance of plants in recently burned and unburned environments. Ecology, 80, 2427-2434. https://doi.org/10. 1890/0012-9658(1999)080[2427:PPOPIR]2.0.CO;2

Valone, T. J. (2003). Examination of interaction of effects of multiple disturbances on arid plant community. Southwestern Naturalist, 48, 481490. https://doi.org/10.1894/0038-4909(2003)048\&lt;0481: EOIEOM\&gt;2.0.CO;2

Valone, T. J., \& Kelt, D. A. (1999). Fire and grazing in a shrub-invaded arid grassland community: Independent or interactive ecological effects? Journal of Arid Environments, 42, 15-28. https://doi.org/10. 1006/jare.1999.0500

Van De Vijver, C. A. (1999). Fire and life in Tarangire: effects of burning and herbivory on an East African savanna system (PhD Thesis). Wageningen University.

Van Langevelde, F., Van De Vijver, C. A., Kumar, L., Van De Koppel, J., De Ridder, N., Van Andel, J., ... Prins, H. H. (2003). Effects of fire and herbivory on the stability of savanna ecosystems. Ecology, 84, 337-350. https://doi.org/10.1890/0012-9658(2003)084[0337: EOFAHO]2.0.CO;2

Walker, B. H., Ed. (1987). Determinants of tropical savannas. Oxford, UK: IRL Press.

Weiher, E., Van Der Werf, A., Thompson, K., Roderick, M., Garnier, E., \& Eriksson, O. (1999). Challenging Theophrastus: A common core list of plant traits for functional ecology. Journal of Vegetation Science, 10, 609-620. https://doi.org/10.2307/3237076

Williams, R. J., Cook, G. D., Gill, A. M., \& Moore, P. H. R. (1999). Fire regime, fire intensity and tree survival in a tropical savanna in northern Australia. Australian Journal of Ecology, 24, 50-59. https://doi. org/10.1046/j.1442-9993.1999.00946.x

Zhang, W. (1998). Changes in species diversity and canopy cover in steppe vegetation in Inner Mongolia under protection from grazing. Biodiversity and Conservation, 7, 1365-1381. https://doi.org/10.1023/ A:1008852017493

\section{SUPPORTING INFORMATION}

Additional supporting information may be found online in the Supporting Information section at the end of the article.

How to cite this article: Nyakunga OC, Vecchio SD, Buffa G. Effects of management regimes on structure, composition and diversity of seasonally inundated herbaceous communities in the Mkomazi National Park, Tanzania. Afr J Ecol. 2018;56:949-956. https://doi.org/10.1111/aje.12524 